\title{
Kerahasiaan Bank Kontra Akses Informasi Perpajakan Ditinjau Dari Maqashid Syari’ah Multidimensi
}

\author{
Mu'adil Faizin \\ Institut Agama Islam Negeri Metro \\ Email : muadilfaizin@gmail.com
}

\begin{abstract}
The issuance of Law No. 9 of 2017 concerning Establishment of PERPU No. 1 of 2017 Becoming an Act not only signals the end of the Bank's confidentiality era, but also shows the limitations of juridical studies in resolving conflicts of interest in law. Therefore, in this paper there will be an examination through the theory of Maqashid Shari'ah, with the hope of mapping the contradictions between the existing norms of rules, and then finding patterns of resolution through multidimensional studies that are free from rigid legal normativity. From the results of the study it was found that according to the normative juridical perspective, the cancellation of the Bank's Confidentiality provisions for taxation information in the event of a legal conflict was the most likely offer to be implemented. This perspective is most likely to be applied despite the limitations of classical normative juridical studies, which only examine in a monodimensional, and rigid manner. Meanwhile in the analysis using the perspective of Maqashid Syari'ah which is Multidimensional, two offers are found to resolve patterns of legal conflict, namely making the needs / conditions of state emergencies as part of Priority Maqashid, or making Protection a part of priority Maqashid, by combining the goals / the purpose of Bank Confidentiality (customer protection), the purpose / purpose of Accessing Tax Information (state development), becomes a new principle, namely, the principle of Customer Health.
\end{abstract}

Keywords: Legal Contradictions, Maqashid Syari'ah Multidimensional, Bank Secrecy, Tax Information Acces.

Abstrak
Terbitnya Undang-Undang No. 9 Tahun 2017 tentang Penetapan PERPU No. 1
Tahun 2017 Menjadi Undang-Undang (selanjutnya disebut UU NO. 9 TAHUN
2019), tidak saja memberi sinyal berakhirnya era Kerahasiaan Bank, namun juga
menampakkan keterbatasan kajian yuridis dalam menyelesaikan pertentangan
hukum/legal contradiction. Karenanya, dalam tulisan ini akan dilakukan
penelisikan melalui teori Maqashid Syari'ah, dengan harapan dapat memetakan
pertentangan antar norma aturan yang ada, dan kemudian menemukan pola
penyelesaian melalui kajian multidimensi yang bebas dari normativitas hukum
yang kaku. Dari hasil kajian ditemukan bahwa menurut persepektif yuridis
normatif, pembatalan ketentuan Kerahasiaan Bank untuk informasi perpajakan
saat terjadi pertentangan hukum adalah tawaran yang paling memungkinkan untuk
diterapkan. Perspektif ini memang paling mungkin untuk diterapkan meskipun
menampakkan keterbatasan kajian yuridis normatif klasik, yang hanya mengkaji
secara monodimensi, dan kaku. Sementara itu dalam analisis menggunakan


Kerahasiaan Bank Kontra..

perspektif Maqashid Syari'ah yang Multidimensi, ditemukan dua tawaran pola penyelesaian pertentangan hukum, yaitu menjadikan kebutuhan/kondisi darurat negara sebagai bagian dari Maqashid yang Prioritas, atau menjadikan Proteksi sebagai bagian dari Maqashid yang prioritas, dengan cara menggabungkan tujuan/maksud dari Kerahasiaan Bank (perlindungan nasabah), tujuan/maksud dari Akses Informasi Perpajakan (pembangunan negara), menjadi sebuah prinsip baru yaitu prinsip Kesehatan Nasabah.

Kata kunci: Pertentangan Hukum, Maqashid Syari'ah Multidimensi, Kerahasiaan Bank, Akses Informasi Perpajakan.

Istinbath: Jurnal Hukum

Website : http://e-journal.metrouniv.ac.id/index.php/istinbath/index

Received : 2020-01-11| Reviewed : 2020-05-18| Published : 2020-05-31.

(c) (1) (2) This is an open access article distributed under the terms of the Creative Commons Attribution 4.0 International License, which permits unrestricted use, distribution, and reproduction in any medium, provided the original work is properly cited.

\section{Pendahuluan}

Secara historis, terdapat satu ketentuan yang sangat berpengaruh dalam menarik kepercayaan nasabah untuk menggunakan jasa perbankan, ketentuan tersebut adalah ketentuan tentang Kerahasiaan Bank. ${ }^{1}$ Ketentuan ini dalam waktu yang lama tak pernah diusik atau berubah, tujuan dan maksud utamanya adalah menjamin keamanan nasabah, ${ }^{2}$ selain itu orientasi perbankan umumnya didominasi oleh kepentingan para nasabah, ${ }^{3}$ sehingga dalam perkembangannya ketentuan ini justru dipertegas menjadi salah satu prinsip dasar dalam mengelola industri perbankan. ${ }^{4}$

Prinsip Kerahasiaan Bank, sebenarnya mempunyai syarat pengecualian untuk kepentingan tertentu, ${ }^{5}$ misalnya, dalam kebutuhan akan informasi perpajakan, ${ }^{6}$ dengan prosedur permintaan izin kepada pimpinan Bank Indonesia, serta syarat bahwa wajib

\footnotetext{
${ }^{1}$ Djoni S. Gazali dan Rachmadi Usman, Hukum Perbankan (Jakarta: Sinar Grafika, 2012), 489.

${ }^{2}$ Kasmir, Dasar-Dasar Perbankan (Jakarta: Raja Grafindo, 2012), 62.

${ }^{3}$ Marnia Rani, "Perlindungan Otoritas Jasa Keuangan Terhadap Kerahasiaan Dan Keamanan Data Pribadi Nasabah Bank," SELAT 2, no. 1 (Oktober 2014): 168-69.

${ }^{4}$ David Chaikin, "Policy And Fiscal Effects Of Swiss Bank Secrecy," REVENUE LAW JOURNAL 15, no. 01 (Januari 2005): 5.

5Jundiani, Pengaturan Hukum Perbankan Syariah Di Indonesia (Malang: UIN Malang Press, 2009), 177-90.

${ }^{6}$ Pasal 41 dalam “UU No. 21 Tahun 2008 tentang Perbankan Syariah” (t.t.).
} 
pajak yang sudah terindikasi melakukan tindak penyelewengan atau pidana perpajakan. ${ }^{7}$ Tetapi dalam perkembangannya posedur dan syarat tersebut dinilai menjadi kendala bagi otoritas perpajakan untuk mengkakses informasi di industri keuangan. ${ }^{8}$

Pemerintah Indonesia beberapa waktu yang lalu pernah berupaya untuk memasifkan kembali upaya meningkatkan penerimaan negara dari sektor perpajakan, ${ }^{9}$ guna menjadi sumber dana utama dalam menopang penyelenggaraan dan aktivitas pemerintahan. ${ }^{10}$ Arah kebijakan ini, semakin terlihat dari terbitnya PERPU No.1 Tahun 2017 tentang Akses Informasi Keuangan Untuk Kepentingan Perpajakan. PERPU tersebut berfungsi sebagai aturan domestik mengenai kewenangan otoritas perpajakan untuk mengakses informasi keuangan dalam kepentingan perpajakan disesuaikan dengan perjanjian internasional AEOI (The Automatic Exchange of Information). ${ }^{11}$ Selanjutnya, pada tanggal 27 Agustus 2017, Pemerintah Indonesia melalui persetujuan Presiden dan DPR telah mengesahkan Undang-Undang No. 9 Tahun 2017 (selanjutnya dapat pula disebut dengan UU NO. 9 TAHUN 2019) tentang Penetapan PERPU NO.1 TAHUN 2017 Menjadi undang-undang. Secara yuridis, UU NO. 9 TAHUN 2019 telah memperkuat kewenangan otoritas perpajakan dalam industri perbankan. ${ }^{12}$

Pada gilirannya, ilustrasi dari Andres dan Markus "is the era of banking secrecy over?"13 menjadi sangat mungkin terjadi, bila sistem kerahasiaan bank dibuka untuk informasi pajak sebagaimana disepakati dalam perjanjian internasional. ${ }^{14}$ Ilustrasi diatas sangat relevan bila melihat arah kebijakan pemerintah/politik hukum yang ada dalam aturan tersebut, sebab terdapat penjelasan di Pasal 8 dalam UU NO. 9 TAHUN 2019

\footnotetext{
${ }^{7}$ Disebutkan: "Dalam hal pihak-pihak sebagaimana dimaksud pada ayat (1) terikat oleh kewajiban merahasiakan, untuk keperluan pemeriksaan, penagihan pajak, atau penyidikan tindak pidana di bidang perpajakan, kewajiban merahasiakan tersebut ditiadakan, kecusali untuk bank, kewajiban merahasiakan ditiadakan atas permintaan tertulis dari Menteri Keuangan." Lihat dalam Pasal 35 angka (2) "UU No. 28 Tahun 2007 Tentang Perubahan Ketiga Atas UU No. 6 Tahun 1983 Tentang Ketentuan Umum Dan Tata Cara Perpajakan" (t.t.).

8 Lihat Penjelasan Umum dari "PERPU No. 1 Tahun 2017 Tentang Akses Informasi Keuangan Untuk Kepentingan Perpajakan" (t.t.).

${ }^{9}$ Mu'adil Faizin, "The Sharia Law Politics Law in Indonesia Year 2008-2017," Adzkiya: Jurnal Hukum dan Ekonomi Syariah 5, no. 2 (1 September 2017): 378-79.

${ }^{10}$ Adrian Sutendi, Hukum Pajak (Jakarta: Sinar Grafika, 2011), 61.

${ }^{11}$ PERPU No. 1 Tahun 2017 Tentang Akses Informasi Keuangan Untuk Kepentingan Perpajakan.

12 Pasal 1 dan 2PERPU No. 1 Tahun 2017 Tentang Akses Informasi Keuangan Untuk Kepentingan Perpajakan.

${ }^{13}$ Andres Knobel dan Markus Meinzer, "The End Of Bank Secrecy? Bridging The GapTo Effective Automatic Information Exchange," Tax Justice Network, 2014, 53.

${ }^{14}$ Olga Balakina dan Donato Masciandaro, Banking Secrecy And Global Finance (New York: Palgrave Macmillan, 2015), 1-2.
} 
Kerahasiaan Bank Kontra..

bahwa berkaitan dengan bidang Akses Informasi Perpajakan, sehingga "Pasal 40 dan 41 Undang-Undang No. 10 Tahun 1998 tentang Perbankan" (selanjutnya dapat disebut pula dengan UU Perbankan), serta "Pasal 41 dan 42 Undang-Undang No. 21 Tahun 2008 tentang Perbankan Syariah" (selanjutnya dapat disebut pula dengan UU Perbankan Syariah), sudah tidak berlaku. Dengan demikian semakin jelas bahwa Kerahasiaan Bank, mungkin akan segera hilang dari peredaran ketentuan industri perbankan.

Dari pemaparan diatas dapat diketahui bahwa telah terjadi pertentangan kepentingan hukum antara kerahasiaan bank dan akses informasi perpajakan. Selama ini, pertentangan hukum selalu diselesaikan secara monodimensi, artinya memihak salah satu dan menegasikan yang lain. Sementara itu, penyelesaian pertentangan pertentangan hukum dengan cara melihat dan mengkaji kandungan maksud dan tujuan setiap ketentuan hukum jarang dipilih sebagai opsi. ${ }^{15}$ Konsekuensinya, alih-alih menyelesaikan masalah, penyelesaian menggunakan perspektif monodimensi justru memperlihatkan hukum sebagai sesuatu yang bersifat kaku, dan lengkap dengan kegagalan menemukan solusi dari pertentangan hukum yang ada. Karena itu, melakukan kajian dan analisa atas pertentangan hukum yang ada menggunakan kacamata Maqashid Syariah menjadi penting.

Maqashid Syariah merupakan sebuah metode ijtihad hukum yang responsif, ${ }^{16}$ sekaligus merupakan sebuah teori ijtihad yang progresif, ${ }^{17}$ karena mampu menghadirkan pertimbangan dengan kajian yang multidimensi, ${ }^{18}$ walaupun untuk menemukan dan menghasilkan pertimbangan yang demikian, mujtahid harus benarbenar memfokuskan diri dan pemikirannya. Maka, akan menjadi menarik untuk mengkaji lebih lanjut dan lebih mendalam, tentang bagaimana konsep yang dimiliki oleh hukum umum dalam meneyelesaikan pertentangan ini, dikomparasikan dengan kosep penyelesaian pertentangan hukum/legal contradiction yang ditawarkan oleh teori maqshid syari'ah. Sehingga kemudian bisa dihasilkan sebuah jalan keluar yang applicable berkenaan dengan pertentangah hukum ini.

\footnotetext{
${ }^{15}$ Jasser Auda, Membumikan Hukum Islam Melalui Maqashid Syariah, trans. oleh Rosidin dan 'Ali 'Abd el-Mun'im (Bandung: Mizan, 2015), 284-89.

${ }^{16}$ Maulidi, "Metodologi ljtihad Fikih Kontemporer (Telaah Atas Pemikiran Yusuf Al-Qaradawi)," AlManahij 8, no. 01 (Januari 2014): 20.

${ }^{17}$ Maulidi Maulidi, “Paradigma Progresif dan Maqashid Syariah: Manhaj Baru Menemukan Hukum Responsif," Asy-Syir'ah Jurnal Ilmu Syari'ah dan Hukum 49, no. 2 (2015): 263-263.

${ }^{18}$ Auda, Membumikan Hukum Islam Melalui Maqashid Syariah, 290.
} 


\section{Pembahasan}

Pada pendahuluan telah disampaikan bahwa Pemerintah Indonesia beberapa waktu ke belakang pernah berupaya meningkatkan penerimaan negara dari sektor perpajakan, sebagai salah satu sumber dana utama dalam penyelenggaraan negara dan aktivitas pemerintahan. Kebijakan ini kemudian dikonkritkan dalam bentuk "PERPU No.1 Tahun 2017 tentang Akses Informasi Keuangan Untuk Kepentingan Perpajakan”. PERPU ini memberikan kewenangan kepada otoritas perpajakan untuk mengakses informasi keuangan dalam kepentingan perpajakan sebagaimana telah disepekatai dalam perjanjian AEOI (The Automatic Exchange of Information). Selanjutnya, untuk memperkuat PERPU ini, Pemerintah dan DPR mengesahkan Undang-Undang No. 9 Tahun 2017 tentang Penetapan PERPU No 1 Tahun 2017 Menjadi undang-undang. Sehingga Secara yuridis normatif, kewenangan otoritas perpajakan untuk dapat melakuan akses kedalam industri perbankan memiliki dasar hukum yang kuat.

Sebagaimana diketahui bahwa dalam industri perbankan terdapat mekanisme Kerahasiaan Bank, yang mengharuskan otoritas pepajakan dengan prosedur perizinan bila hendak mengakses rahasia nasabah dari suatu perbankan, ${ }^{19}$ hal ini berbanding terbalik dengan mekanisme yang terkandung dalam UU NO. 9 TAHUN 2019, yang mengharuskan wajib pajak dan atau pihak perbankan, mendaftarkan diri untuk menyampaikan informasi keuangan secara otomatis. ${ }^{20}$ Dari fakta tersebut, terlihat perbedaan dan pertentangan kepentingan hukum dari dua norma hukum yang samasama berlaku dan diakui.

\section{Pertentangan Kerahasiaan Bank Dan Akses Informasi Perpajakan}

Melihat skema ketentuan dari Kerahasiaan Bank berdasarkan UU Perbankan/UU Perbankan Syariah, dengan Akses Informasi Perpajakan berdasarkan UU NO. 9 TAHUN 2019, dapat dipastika terdapat beberapa perbedaan yang mendasar. Untuk mengetahui perbedaan mendasarnya, maka akan dilakukan perbandingan sistematis dari kedua UU tersebut dalam sebuah tabel yang tercantum di bawah ini:21

\footnotetext{
${ }^{19}$ Lihat UU No. 10 Tahun 1998 yang dirumuskan dalam ketentuan Pasal 1 angka 28, sertaUU No. 21 Tahun 2008 tentang Perbankan Syariah.

${ }^{20}$ Lihat Pasal 1-4 dari "UU No. 9 Tahun 2017 Tentang Penetapan PERPU No. 1 Menjadi UndangUndang".

${ }^{21}$ Mu'adil Faizin, “Analisis Maqāșid Asy-Syarī’ah Terhadap Prinsip Kerahasiaan Bank Dan Akses Informasi Perpajakan" (masters, UIN SUNAN KALIJAGA YOGYAKARTA, 2018), 72, http://digilib.uinsuka.ac.id/30705/.
} 
Tabel 1

Komponen Perbandingan

\begin{tabular}{|l|l|l|}
\hline No & Kerahasiaan Bank & Akses Informasi Perpajakan \\
\hline 1. & Paradigma perlindungan & Paradigma penertiban \\
2. & Metode perizinan & Metode pendaftaran \\
3. & Prosedur: Menteri Keuangan & Prosedur: LJK menyampaikan \\
& meminta Pimpinan Bank & kepada Dirjen Pajak melalui OJK, \\
& $\begin{array}{l}\text { Indonesia untuk mengeluarkan } \\
\text { perintah tertulis kepada Bank }\end{array}$ & LJK Lainnya dan Entitas Lainnya \\
& melaporkan kepada Dirjen Pajak. \\
\hline
\end{tabular}

Tiga komponen di atas merupakan perbedaan yang paling menonjol dari Kerahasiaan Bank dan Akses Informasi Perpajakan. Kerahasiaan Bank memiliki paradigma melindungi nasabah agar nyaman menggunakan jasa keuangan di bank, sekaligus terhadapnya terhindar dari tindak kriminal. Sedangkan paradigma Akses Informasi Perpajakan adalah ketertiban, dengan maksud agar setiap warga negara dapat menjalankan kewajibannya untuk membayar pajak, dilengkapi dengan keniscayaan akan kebutuhan negara dalam pendapatan pajak. ${ }^{22}$

Metode yang digunakan untuk mengakses informasi berdasarkan Kerahasiaan Bank yaitu dengan perizinan, dari Menteri Keuangan selaku pemohon izin, kepada pimpinan Bank Indonesia selaku pemberi izin. Sementara dalam Akses Informasi Perpajakan tidak dibutuhka prosedur perizinan, dengan kata lain metode yang digunakan adalah metode pendaftaran, artinya, pihak lembaga jasa keuangan mendaftarkan diri ke Dirjen Pajak, agar secara otomatis dapat melaporkan informasi kepada Dirjen Pajak melalui OJK, atau langsung kepada Dirjen Pajak. ${ }^{23}$

Di poin inilah letak pertentangan yang paling radikal dari objek penelitian, Peraturan perizinan dalam pembukaan informasi perpajakan yang merupakan salah satu komponen ketentuan Kerahasiaan Bank, ${ }^{24}$ bertentangan secara materil dengan peraturan pendaftaran dalam Akses Informasi Perpajakan. ${ }^{25}$

\footnotetext{
${ }^{22}$ Faizin, 72-73.
}

${ }^{23}$ Faizin, 73.

${ }^{24}$ Lihat Pasal 41 UU No. 10 Tahun 1998 Tentang Perbankan, Pasal 42 UU No. 21 Tahun 2008 Tentang Perbankan Syariah, serta Pasal 35UU No. 28 Tahun 2007 Tentang Perubahan Ketiga Atas UU No. 6 Tahun 1983 Tentang Ketentuan Umum Dan Tata Cara Perpajakan.

${ }^{25}$ Lihat Pasal 2 UU No. 9 Tahun 2017 Tentang Penetapan PERPU No. 1 Menjadi Undang-Undang. 


\section{Analisis Yuridis Terhadap Pertentangan}

Dalam rangka analisa mendalam tentang fenomena pertentangan hukum ini, peneliti mencoba mengkaji dengan berpedoman kepada beberapa asas yang berlaku menurut teori hukum yuridis, di antaranya:

1. Asas Hierarki

Berpedoman asas hierarki ini, maka setiap Undang-undang, satu sama lain memiliki tingkatan yang sama. UU Perbankan, UU Perbankan Syariah, UU KUP dan UU NO. 9 TAHUN 2019 pada dasarnya memiliki kedudukan yang sejajar. PERPU juga merupakan peraturan yang mempunyai hierarki setingkat dengan Undang-Undang. PERPU ditetapkan oleh Presiden dalam keadaan kegentingan yang memaksa pada saat itu dan harus segera diatasi, sedangkan Presiden tidak menemukan perangkat hukum dalam peraturan perundang-undangan yang ada. ${ }^{26}$ PERPU memiliki jangka waktu yang terbatas, karena secepat mungkin harus dimintakan persetujuan dari Dewan Perwakilan Rakyat dalam sidang DPR. Apabila disetujui akan menjadi Undang-Undang, namun jika tidak disetujui akan dicabut saat itu juga. ${ }^{27}$

Berkaitan dengan PERPU NO.1 TAHUN 2017, dalam kurun waktu kurang-lebih dua bulan, Presiden dan DPR telah mengesahkan UU NO. 9 TAHUN 2019, itu artinya PERPU NO.1 TAHUN 2017 sudah menjalani proses sesuai teori trias politika sehingga telah ditetapkan sebagai salah satu Undang-undang yang berlaku. Jika berpedoman asas hierarki, maka tidak salah bila kemudian muncul pemahaman yang menyatakan bahwa sebenarnya UU NO. 9 TAHUN 2019, tidak dapat membatalkan UU Perbankan, UU Perbankan Syariah, dan UU KUP, karena semua UU tersebut memiliki kedudukan sejajar dan sederajat. Adapun kemudian, bila terjadi direvisi peraturan perundangundangan akibat terbitnya UU NO. 9 TAHUN 2019, maka perubahan tersebut tetap sah karena disepakati dalam sidang DPR, meskipun dipengaruhi oleh kosntruksi Politik yang ada saat itu, dan bukan dipengaruhi oleh UU NO. 9 TAHUN 2019. ${ }^{28}$ Akan tetapi akan terjadi tumpang tindih peraturan, dan ketidakpastian hukum apabila asas ini diterapkan sebagai dasar pemikiran dalam analisis hukum, dan tentu itu merupakan hal buruk bagi sebuah negara hukum seperti indonesia yang termasuk negara berkembang.

${ }^{26}$ Agus Surono, Fiksi Hukum Dalam Pembuatan Peraturan Perundang-Undangan (Jakarta: UAI, 2013), 37-38.

${ }^{27}$ Surono, 38.

${ }^{28}$ Faizin, "Analisis Maqāșid Asy-Syarīah Terhadap Prinsip Kerahasiaan Bank Dan Akses Informasi Perpajakan," 76. 
Kerahasiaan Bank Kontra..

\section{Asas Specialis Derogate Legi Generalis}

Keberadaan asas ini menegaskan bahwa peraturan lebih khusus mengecualikan peraturan yang lebih umum. Bahwa ketika telah dibuat suatu peraturan yang mengatur lebih khusus dalam suatu bidang tertentu, maka serta merta keberadaan peraturan ini akan mengecualikan peraturan yang sebelumnya bersifat umum. ${ }^{29}$

Berlandaskan pedoman asas ini, UU NO. 9 TAHUN 2019 sebagai aturan khusus berkaitan Akses Informasi Perpajakan menjadi lebih kuat posisinya ketimbang ketentuan Kerahasiaan Bank. Karena, informasi perpajakan yang diatur oleh Kerahasiaan Bank hanyalah salah satu dari banyak pengecualian. Ditambah lagi, ketentuan pengecualian Kerahasiaan Bank, masih menginduk dengan UU Perbankan, UU Perbankan Syariah, UU Pasar Modal, UU Asuransi, dan UU KUP. Singkatnya, ketentuan Kerahasiaan Bank berkaitan pengecualian perpajakan hanya bagian pasal dalam peraturan tentang Lembaga Jasa Keuangan (LJK), belum berdiri sendiri sebagaimana UU NO. 9 TAHUN 2019 yang mengatur Akses Informasi Perpajakan.

Berdasarkan pedoman dua asas yuridis di atas, penetapan UU NO. 9 TAHUN 2019 menjadi sah secara hukum dan kedudukannya sama dengan Undang-Undang yang lain. Namun, UU NO. 9 TAHUN 2019 memiliki posisi yang lebih kuat ketimbang Undang-Undang yang lain dalam bidang yang berkaitan dengan Akses Informasi Perpajakan, sehingga ketentuan Kerahasiaan Bank terkait pengecualian untuk kepentingan pajak menjadi tunduk terhadapnya.

Apabila menggunakan asas ini kemudian pembahasan dihentikan, maka solusi dari pertentangan hukum antara Kerahasiaan Bank dan Akses Informasi Perpajakan adalah, pembatalan Pasal 40 dan 41 UU Perbankan, Pasal 41 dan 42 UU Perbankan Syariah, dan Pasal 35 UU KUP, dan diganti dengan ketentuan yang ada pada Pasal 8 UU NO. 9 TAHUN 2019. Dengan kata lain, berdasarkan sudut pandang teori hukum yuridis, ketentuan tentang Akses Informasi Perpajakan menegasikan ketentuan tentang Kerahasiaan Bank. Dengan demikian, hal ini menunjukkan bahwa apa yang dituturkan oleh ahli hukum Islam seperti Jasser Auda, sebagai ketidakmampuan dan keterbatasan pandangan monodimensi dalam penyelesaian pertentangan adalah benar adanya. Sehingga harus ada formulasi lain yang memungkinkan untuk memecahkan kebuntuan dalam menyelesaikan pertentangan hukum yang terjadi.

\footnotetext{
${ }^{29}$ Surono, Fiksi Hukum Dalam Pembuatan Peraturan Perundang-Undangan, 97.
} 


\section{Pola Penyelesaian Pertentangan Kerahasiaan Bank Dan Akses Informasi Perpajakan}

Tema pertentangan (tanakud) antar teks dari dalil atau ketentuan sudah tidak terlalu asing dalam kajian hukum Islam. Fenomena pertentangan ini pula yang mendorong munculnya terminologi konsiliasi, nasikh mansukh, tarjih, tawaqquf, tasaqut, dan takhyir. Keenam terminologi ini adalah strategi para fakih untuk menghadapi perselisihan dalam mazhab-mazhab fikih tradisional. ${ }^{30}$

Dalam rangka menghadirkan solusi dari pertentangan hukum, ${ }^{31}$ Jasser Auda menawarkan solusi berfikir yang lain yaitu, Maqashid Syariah yang menelisik secara multidimensi, ${ }^{32}$ yang peneliti sebut sebagai Maqashid Syari'ah Multidimensi. Teori ini akan mampu menghadirkan sebuah solusi dari pertentangan hukum yang ada, tanpa harus mengabaikan dan atau meniadakan inti dan subtansi dari ketentuan-ketentuan yang ada tersebut.

1. Maqashid Dari Ketentuan Kerahasiaan Bank Dan Akses Informasi Perpajakan

Pada hakikatnya, ketentuan tentang Kerahasiaan Bank telah dipengaruhi oleh komponen politik yang menjadikan kepentingan nasabah sebagai intinya, selain itu, ketentuan ini juga dipengaruhi komponen ekonomi, yang orientasi intinya adalah kemanfaatan dana. Kemudian, Kepentingan nasabah dan kemanfaatan dana ini bertemu dan dielaborasi sedemekian rupa dalam norma prinsipal yang output-nya berupa perlindungan nasabah. Dalam awal perjalanannya, perlindungan nasabah ini didukung oleh budaya pertumbuhan industri perbankan dan proses menarik simpati nasabah, sehingga dimaknai menjadi ketentuan Kerahasiaan Bank.

Di sisi lain, ketentuan Akses Informasi Perpajakan, dipengaruhi oleh komponen politik yang menjadikan kepentingan negara sebagai prioritas utama. Selain itu, komponen ekonominya orientasi intinya adalah kebijakan pembangunan. Ide inti yang berupa kepentingan negara dan kebijakan pembangunan, kemudian bertemu dalam norma prinsipal yang menghendaki output berupa pembangunan negara. Perbedaan budaya antara era pra dengan pasca standar AEOI telah membuat perbedaan pandangan

\footnotetext{
${ }^{30}$ Faizin, “Analisis Maqāșid Asy-Syarī’ah Terhadap Prinsip Kerahasiaan Bank Dan Akses Informasi Perpajakan," 96.

${ }^{31}$ Muhammad Lutfi Hakim, "Pergeseran Paradigma Maqasid Al-Syari'ah: Dari Klasik Sampai Kontemporer," Al-Manahij 10, no. 01 (Juni 2016): 8-9.

${ }^{32}$ Abbas Arfan, "Maqasid Al-Syariah Sebagai Sumber Hukum Islam, Analisis Terhadap Pemikiran Jasser Auda," Al-Manahij 07, no. 01 (Juli 2013): 190.
} 
Kerahasiaan Bank Kontra..

dunia dalam memaknai pembangunan negara. Awalnya norma prinsipal tentang Informasi Perpajakan tersebut eksistensinya disesuaikan dengan ketentuan Kerahasiaan Bank, namun pasca digunakannya standar AEOI, eksistensi ketentuan terdahulu juga berubah menjadi ketentuan yang harus menyesuaikan dengan standar AEOI yang dijadikan acuan bagi banyak ketentuan, temasuk bagi Kerahasiaan Bank.

Perenungan terhadap Kerahasiaan Bank dan Akses Informasi Perpajakan telah menunjukkan bahwa pertentangan keduannya dikarenakan situasi dan kondisi kognitif yang telah mempengaruhinya. Ditemukan pula sisi kebermaksudan dari Kerahasiaan Bank berupa perlindungan nasabah, sementara Akses Informasi Perpajakan bermaksud pada pembangunan negara.

\section{Keterbatasan Pandangan Monodimensi}

Pertentangan hukum, selain didasari oleh pengaruh atas situasi dan kondisi kognitif, juga didasari oleh kandungan prinsip yang berbeda (perlindungan nasabah dan pembangunan negara). Dalam referensi fikih tradisional, solusi pertentangan dalil semacam ini sering diselesaikan dengan metode nasakh (nasikh mansukh/saling menegasikan) yang melihat dengan monodimensi. Berupaya mengurai perselisihan diakhiri dengan langkah menghapus masing-masing dan setiap dalil yang bertentangan. ${ }^{33}$ Pola umumnya yaitu dalil yang terbit terakhir menghapus seutuhnya dalil yang diterbitkan sebelumnya. ${ }^{34}$ Pola yang tak jauh beda dengan apa yang dinampakkan oleh keterbatasan kajian yuridis dalam menyikapi pertentangan objek penelitian.

Problem yang terjadi akibat metode saling menegasikan(naskhu al-hukm) ini adalah, hasil penyelesaian pertentangan yang cenderung menjadi pilihan kaku yang terkadang memaksakan untuk diterapkan pada setiap tempat, waktu, maupun situasi dan kondisi. Celakanya, saling menegasikan (naskhu al-hukm) menjadi sebuah metode pembatalan keabsahan pendapat-pendapat atau dalil-dalil yang disahkan oleh mazhab fikih rival. Penggunaan metode saling menegasikan (naskhu al-hukm) ini telah

\footnotetext{
${ }^{33}$ Auda, Membumikan Hukum Islam Melalui Maqashid Syariah, 288.

${ }^{34}$ Jasser Auda, Al-Maqashid Untuk Pemula, trans. oleh Ali Abdelmon im (Yogyakarta: SUKA Press,
} 2013), 64. 
memperbanyak problem kurangnya interpretasi Multidimensi terhadap dalil-dalil, ${ }^{35}$ dan tampak belum maksimal mencarikan solusi ketegangan dinamika hukum. ${ }^{36}$

Problem serupa pun akan terjadi pada ketentuan Kerahasiaan Bank dengan Akses Informasi Perpajakan, jika diselesaikan secara saling menegasikan (naskhu alhukm) dan dilihat dengan dimensi tunggal saja, maka penyelesaian akan menjadi sangat terbatas dan berhenti pada pembenaran atas salah satu ketentuan antara secrecy (Kerahasiaan Bank), atau transparency (Akses Informasi Perpajakan) saja. Pembenaran ini juga akan berimplikasi pada kecedrungan dan keberpihaka, artinya harus mengutamakan pemihakkan kepentingan nasabah atau negara. Dengan demikian hukum yang progresif dan dinamis akan sulit terwujud.

3. Analisis Maqashid Syari'ah Multidimensi

Jika upaya memperluas jangkauan pandangan dilakukan, dengan cara memasukkan berbagai dimensi yang mendukung dan berkaitan dengan kontekstualisasi hukum, makan akan ada kemungkinan yang muncul dari ketentuan-ketentuan yang dianggap bertentangan itu, menjadi saling mendukung dan menopang dalam mencapai maksud tertentu, dengan tetap mempertahankan konteksnya yang berbeda-beda. Kedua ketentuan tersebut dapat dikonsiliasi pada suatu konteks baru, yaitu konteks Maqashid, ${ }^{37}$ yang dalam tulisan ini disebut dengan Maqashid Syari'ah Multidimensi.

Menariknya, teori Maqashid bukan hanya memberi jalan baru bagi pertimbangan berbagai maksud serta dimensi lain, tetapi juga membuka ruang persandingan berbagai teori yang lain. Pada bagian ini, teori Maqashid Syariah telah bergumul dengan Politik Hukum. Pergumulan kedua teori ini sering menggugah kesadaran baru yang sebelumnya tak pernah terpikirkan. Dalam karya Yudian Wahyudi, persapaan antara Maqashid Syariah dan Politik Hukum sempat didemonstrasikan untuk menganalisis konflik Islam dan nasionalisme. Membuktikan bahwa langkah politik atau sebuah Politik Hukum beberapa di antaranya memiliki nilai dan timbangan syariah. Bermaksud untuk tidak menyia-nyiakan teori yang luar biasa ini, ${ }^{38}$ peneliti juga

\footnotetext{
${ }^{35}$ Auda, Membumikan Hukum Islam Melalui Maqashid Syariah, 290.

${ }^{36}$ Mufti Hasan, "Mekanisme Penyelesaian Ayat Kontradiktif Berbasis Maqasid Al-Shariah: Studi Terhadap Ayat Perkawinan Beda Agama," THEOLOGIA 28, no. 01 (Juni 2017): 125.

${ }^{37}$ Auda, Membumikan Hukum Islam Melalui Maqashid Syariah, 290.

${ }^{38}$ Yudian Wahyudi, Hukum Islam Antara Filasafat Dan Politik (Yogyakarta: Pesantren Nawasea Press, 2015), 73-74.
} 
Kerahasiaan Bank Kontra..

melakukan hal yang serupa. Di bawah ini pembahasan terhadap objek penelitian dilihat dari kajian Syariah dan Politik Hukum Ekonomi:

1. Kajian Syariah

Pada umumnya, ruang lingkup yang dipelihara oleh Maqashid Syariah sering dibagi menjadi lima komponen, ${ }^{39}$ terangkum dalam sebutan al-uṣul al-khamsah (prinsip yang lima $)^{40}$ sebagai ukuran tegaknnya kehidupan manusia, ${ }^{41}$ atau al-uṣul alkuliyyāt, ${ }^{42}$ terkadang juga disebut al-kuliyyāt al-khamsah. ${ }^{43}$ Prinsip atau tujuan ini berkaitan dengan pemeliharaan agama, jiwa, akal, keturunan dan harta. ${ }^{44}$ Adapun alat untuk menghantarkan kepada tujuan yang sering disebut dengan sarana, tidak ditentukan secara tetap dalam syariat, dapat dipahami bahwa sarana mencapai tujuan selalu bersesuaian dengan konteks. ${ }^{45}$

Segala tindak perbuatan manusia yang menyebabkan terwujud dan terpeliharanya lima prinsip tersebut dinyatakan sebagai perbuatan bermanfaat. Sebaliknya, segala bentuk tindakan manusia yang menyebabkan tidak terwujudnya atau rusaknya salah satu prinsip lima yang merupakan tujuan Allah tersebut, maka perbuatan itu adalah merusak. ${ }^{46}$

Jika ditarik dengan konteks pembuatan ketentuan, maka setiap ketentuan yang arahnya mewujudkan lima prinsip tersebut dapat diartikan menimbulkan manfaat, sebaliknya jika menyebabkan tidak terwujud, ketentuan itu adalah merusak. Menyikapi hal ini, penyelidikan terhadap kandungan syariah pada objek penelitian menjadi perlu.

a. Kerahasiaan Bank

Ketentuan Kerahasiaan Bank sebagai sarana dari perlindungan nasabah, khususnya berkenaan dengan rahasia keadaan keuangan (financial privacy), dalam

${ }^{39}$ Amir Syarifuddin, Ushul Fiqh Jilid 2, Revisi (Jakarta: Kencana, 2014), 233.

${ }^{40}$ Ainol Yaqin, "Revitalisasi Maqashid Al-Syari'ah dalam Istinbath Hukum Islam: Kajian atas Pemikiran Muhammad Al-Thahir Ibnu 'Asyur," Asy-Syir'ah Jurnal Ilmu Syari'ah dan Hukum 50, no. 2 (2016): 321.

${ }^{41}$ Muhammad Ngizzul Muttaqin dan Iffatin Nur, "Menelusuri Jejak Maqashid Syari'ah Dalam Istinbath Hukum Imam Hambali," AHKAM 07, no. 01 (Juli 2019): 158-59.

${ }^{42}$ Samsul Anwar, "Teori Pertingkatan Norma Dalam Ushul Fikih," Asy-Syir'ah 50, no. 01 (Juni 2016): 157-59.

${ }^{43}$ Mu'adil Faizin, "Hak Asasi Manusia Dalam Pemikiran Yusuf Qaradhawi," Al-Mazahib 5, no. 1 (1 Juni 2017): 6, http://ejournal.uin-suka.ac.id/syariah/almazahib/article/view/1388.

${ }^{44}$ Abad Badruzaman, "Dari 'Illah Ke Maqasid: Formula Dinamisasi Hukum Islam Di Era Kekinian Melalui Pengembangan Konsep Maqasid," ljtihad 14, no. 01 (Juni 2014): 72-77.

${ }^{45}$ Khariri, "Penalaran Hukum Islam (Upaya Mensinergikan Metode al-Tsawabit dan alMutaghayyirat)," Al-Manahij 10, no. 01 (Juni 2016): 53.

${ }^{46}$ Syarifuddin, Ushul Fiqh Jilid 2, 232. 
kajian syariah dinilai menjadi ketentuan yang bermanfaat dalam mendukung hifzul $m \bar{a} l$ (pemeliharaan harta). Terbukti dari ketentuan teknis Kerahasiaan Bank yang berorentasi pada perlindungan data nasabah dan simpanannya, sehingga menimbulkan rasa confidence dan aman bagi nasabah perihal keamanan hartanya.

Berlakunya Kerahasiaan Bank dalam kajian syariah merupakan ketentuan yang melaksanakan salah satu dari al-ușul al-khamsah (prinsip yang lima). ${ }^{47}$ Sebagaimana disebutkan dalam surat An-Nisā' ayat 29:

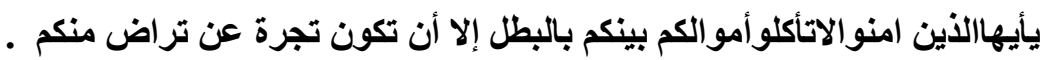

Artinya:

"Hai orang-orang yang beriman, janganlah kamu memakan harta sesamamu secara batil, kecuali yang terjadi dalam transaksi secara suka sama suka." 48

Ayat ini membuktikan bahwa nilai luhur penjagaan terhadap harta adalah salah satu ajaran yang dijaga oleh syariah. ${ }^{49}$ Maksudnya ialah tentang pemeliharaan harta agar tidak dipergunakan atau dirusak oleh orang lain. ${ }^{50}$ Dengan begitu, segala sesuatu berkaitan penjagaan harta terhadap sesama menjadi bagian dari nilai luhur ini. Konteks ayat tersebut memang erat pada transaksi perpindahan harta (jual beli), meski makna universal yang dapat dipahami adalah bahwa setiap penjagaan harta harus disertai ketentuan yang dapat diaplikasikan untuk mendampingi keberjalanan penjagaan harta tersebut. ${ }^{51}$

Dijelaskan pula oleh Al-Jumu'ah ayat 10, terkait dengan kebolehan upaya menjaga eksistensi harta:

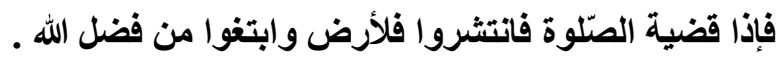

Artinya:

"...bila kamu telah melaksanakan shalat bertebaranlah di atas muka bumi dan carilah rezeki Allah". ${ }^{2}$

\footnotetext{
${ }^{47}$ Syarifuddin, 232.

${ }^{48} \mathrm{Abdullah}$ bin Muhammad bin Abdurahman bin Ishaq Al-Sheikh, Tafsir Ibnu Katsir, vol. II (Bogor: Pustaka Imam Syafii, 2000), 280.

${ }^{49} \mathrm{Al}$-Sheikh, II:281-83.

${ }^{50}$ Safriadi Safriadi, "KONTRIBUSI IBN 'ĀSYŪR DALAM KAJIAN MAQĀSID AL-SYARĪ'AH,” Jurnal IImiah Islam Futura 15, no. 2 (1 Februari 2016): 295-97, https://doi.org/10.22373/jiif.v15i2.546.

${ }^{51}$ Al-Sheikh, Tafsir Ibnu Katsir, 2000, II:281-83.

${ }^{52}$ Abdullah bin Muhammad bin Abdurahman bin Ishaq Al-Sheikh, Tafsir Ibnu Katsir, vol. VIII (Bogor: Pustaka Imam Syafii, 2000), 178.
} 
Kerahasiaan Bank Kontra..

Meminjam redaksi Hans Nawiasky, aturan Kerahasiaan Bank ini bisa disebut verordnung en autonome satzung (aturan pelaksana) ${ }^{53}$ dari Maqashid Syariah berupa pemeliharaan harta. Penafsiran lebih dalamnya, eksistensi Kerahasiaan Bank berbanding lurus dengan eksistensi Maqashid Syariah.

b. Akses Informasi Perpajakan

Ketentuan Akses Informasi Perpajakan sebagai sarana dari pembangunan negara dalam kajian syariah dikenal sebagai pemenuhan hak ulil amri (pemimpin).${ }^{54}$ Perintah taat kepada ulil amri merupakan kewajiban bagi muslim, sepanjang mereka adalah pemimpin yang memiliki ketaatan kepada Allah dan bagi kaum muslimin memberi kebaikan serta kemaslahatan. ${ }^{55}$

Dalil serupa ulil amri ini yang sering disifati sebagai mutagayyirāt (fleksibel), sebab yang $\dot{s} a w a \overline{b i t}$ adalah dalil tentang ketaatan kepada Allah SWT dan Rasul-Nya. ${ }^{56}$ Hal ini berdasarkan surat An-Nisā' ayat 59:

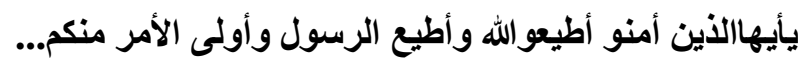

Artinya:

"Hai orang-orang yang beriman, taatilah Allah dan taatilah Rasul-Nya, dan ulil amri di antara kamu..., 57

Jabatan ulil amri dalam perkembangannya dinisbatkan kepada kepemimpinan negara. ${ }^{58}$ Kewajiban ketaatan kepada ulil amri ini berlaku sepanjang tidak mengarah kepada kemaksiatan. ${ }^{59}$ Setidaknya ada lima fungsi negara terkait kepemimpinan yaitu; pelaksanaan dasar-dasar agama Islam; penegakan hukum/ keadilan dan perlindungan hak-hak; pemeliharaan ketertiban dan keseimbangan ekonomi; penyediaan infrastruktur sosial; dan pembelaan

${ }^{53}$ Jimly Asshiddiqie dan M. Ali Safa'at, Teori Hans Kelsen Tentang Hukum (Jakarta: Konpress, 2014), 154-55.

${ }^{54}$ Rapung Samuddin, Fiqih Demokrasi (Jakarta: GOZIAN Press, 2013), 76.

${ }^{55}$ Samuddin, 77.

${ }^{56}$ Samuddin, 38.

${ }^{57}$ Al-Sheikh, Tafsir Ibnu Katsir, 2000, II:337.

${ }^{58}$ Ibn Taimiyah, Siyasah Syar'iyah, trans. oleh Rofi' Munawar (Surabaya: Risalah Gusti, 2005), 3442.

${ }^{59}$ Al-Sheikh, Tafsir Ibnu Katsir, 2000, II:341-42. 
keamanan negara. ${ }^{60}$ Dengan kalimat lain, pembangunan negara merupakan salah satu dari lima fungsi negara.

Mencermati ketentuan Akses Informasi Perpajakan, sehubungan dengan rentetan kajian di atas, masuk sebagai bagian dari fungsi pemeliharaan ketertiban dan keseimbangan ekonomi, selayaknya perpajakan sebagai salah satu sumber penerimaan kas negara. Dalam posisi ini, Akses Informasi Perpajakan jelas merupakan sarana ulil amri untuk pembangunan negara yang tidak diketemukan alasan syariah untuk menolaknya, sehingga Akses Informasi Perpajakan menjadi ketentuan yang tidak dapat ditolak pula secara syariah.

\section{Kajian Politik Hukum Ekonomi}

Produk hukum tertentu merupakan produk politik tertentu juga, ${ }^{61}$ Hukum Ekonomi termasuk dari produk hukum yang tidak lepas dari pengaruh politik. Arah politik suatu negara akan sangat mempengaruhi orentasi Hukum Ekonomi di negara tersebut. ${ }^{62}$ Dalam referensi lama di ilmu ekonomi, perbincangan terkait pengaruh politik terhadap kebijakan ekonomi sering disebut dengan istilah regulasi ekonomi. Secara lebih luas teori regulasi ekonomi ditujukan untuk melihat manfaat dan kerugian dari suatu kebijakan. Regulasi harus diinstitusikan dengan manfaat sebanyak mungkin pada publik atau konstituen yang dikenai regulasi tersebut dengan dampak negatif atau kerugian yang minimal atau bahkan tanpa harus menyebabkan kerugian. ${ }^{63}$

Pembahasan regulasi ekonomi bisa juga mengarah pada analisis suatu peraturan yang berdampak positif pada satu pihak tetapi dapat berdampak negatif pada pihak yang lain. Berkaitan dengan pemberlakuan suatu peraturan, dunia akademis telah mengenal dua alternatif pandangan yaitu proteksi dan proses politik. Proteksi memandang hukum sebagai tujuan perlindungan dan manfaat ekonomi yang diberikan negara, selanjutnya proses politik memandang peraturan lahir sebagai proses permintaan dan penawaran regulasi ekonomi tertentu sebagaimana kontrak politik dalam pemilihan umum. ${ }^{64}$

${ }^{60}$ M.Arskal Salim G.P, Etika Intervensi Negara Perspektif Etika Politik Ibnu Taimiyah (Jakarta: Logos, 1998), 64.

${ }^{61}$ Moh Mahfud MD", Membangun Politik Hukum, Menegakkan Konstitusi (Jakarta: Rajawali Pers, 2010), 28-29.

${ }^{62}$ Faizin, "The Sharia Law Politics Law in Indonesia Year 2008-2017," 378-79.

${ }^{63}$ Ahmad Erani Yustika, Ekonomi Politik (Yogyakarta: Pustaka Pelajar, 2011), 10-11.

${ }^{64} \mathrm{Ahmad}$ Erani Yustika, 12-14. 
Kerahasiaan Bank Kontra..

Berkenaan dengan regulasi bidang ekonomi, khususnya yang berkaitan dengan bank, dalam tulisan ini akan digunakan dua perspektif, dan dengan Pembahasan dua perspektif ini diharapkan dapat mengidentifikasi pola pembentuk hukum, dan dapat filsafat politiknya. Dua alternatif pandangan yang dimaksud adalah sudut pandang kerahasiaan Bank dan Akses Perpajakan.

a. Kerahasiaan Bank

Menurut Miftah Idris, kerahasiaan bank memiliki cakupannya sangat terbatas, antara lain meliputi : a. Segala macam bentuk data yang berkaitan langsung dengan data yang berisi keterangan-keterangan nasabah, baik yang berkaitan dengan uang yang disimpannya ataupun investasi yang dilakukannya; $b$. Pihak bank dan pihak terkait memiliki kewajiban dan tanggung jawab penuh untu menjaga segala rahasia nasabah berkewajiban menjaga segala macam data dan atau keterangan mengenai nasabah selama bentuk transaksi yang dilakukan nasabah bukan merupakan hal yang dilarang oleh undang-undang; c. Informasi terkait nasabah, baik penyimpan maupun investor tidak dibenarkan untuk dibuka kepada siapapun, kecuali ada kondisi yang sangat penting untuk melakukan tindakan tersebut. Kondisi-kondisi penting yang dapat dijadikan Pengecualian atas Rahasia nasabah Bank adalah untuk kepentingan-kepentingan berikut: a. Kepentingan penyidikan, misalnya apabila disinyalir nasabah telah melakukan pelanggaran pidana yang berkaitan dengan perpajakan b. Kepentingan proses peradilan pidana; c. Dan pemeriksaan perdata; d. Information exchange antarbank; e. Adanya pemberian kuasa, dan atau permintaan, dan atau persetujuan nasabah/investor untuk membuka data nasabah; dan f. Adanya permintaan keterangan tentang simpanan nasabah, yang dilakukan oleh Ahli Warisnya. ${ }^{65}$

Adanya Prinsip kerahasaiaan yang diterapkan oleh perusahaan perbankan, tujuannya adalah untuk menjaga kepercayaan para nasabah kepada bank, yang nantinya tentu akan berimplikasi pada kepentingan serta kelancaran dari bisnis perbankan itu sendiri. Bila yang terjadi sebaliknya, dalam artian bank tidak mampu mewujudkan trust dari nasabah dengan cara menjaga kerahasiaan dari segala macam data pribadi terkait nasabahnya, tentu hal ini akan memunculkan

\footnotetext{
${ }^{65}$ Miftah Idris, "Kerahasiaan Bank Suatu Tinjauan Dalam Aturan Hukum Perbankan Syariah Di Indoesia," Al-Amwal: Journal of Islamic Economic Law 1, no. 1 (20 Mei 2019): 1-29, https://doi.org/10.24256 /alw.v1i1.624.
} 
distrust masyarakat kepada bank yang bersangkutan, dan dampaknya tentu adalah keengganan dari nasabah untuk saving dananya pada bank tersebut. Selain untuk menjaga trust, kewajiban yang diberikan oleh OJK kepada para pengusaha dibidang jasa keuangan untuk menaati ketentuan dalam "Peraturan Otoritas Jasa Keuangan (POJK) Nomor 1/POJK.07/2013 Tentang Perlindungan Konsumen Sektor Jasa Keuangan”, merupakan sebab lain dari pentingnya bagi mereka untuk menjaga data nasabahnya. Ketentuan yang dimaksud adalah: a. larangan bagi para pengusaha bidang jasa keuangan untuk menawarkan barang/layanan/produk jasanya kepada masyarakat, sebagai calon konsumen ataupun konsumen tetap, menggungakan media komunikasi privat; b. Larangan bagi pelaku usaha jasa keuangan, baik perbankan atau selainnya, membocorkan dan atau memberikan data/informasi mengenai nasbah dan atau Konsumennya kepada pihak lain. Adapun termasuk kedalam jenis Data/Informasi Pribadi yang wajib dijaga kerahasiaannya, berdasarkan "Surat Edaran Nomor:14/SEOJK.07/2014 Tentang Kerahasiaan dan Keamanan Data dan/atau Informasi Pribadi Konsumen”, adalah, data dalam bentuk apapun yang berkaitan dengan nasabah penyimpan, termasuk nomor kontak telepon pribadi dari nasabah. Berdasarkan peraturan yang ada, maka secara normatif bila ketentuan-ketentuan tadi dilanggar oleh pengusaha jasa keuangan/perbankan, maka pengusaha jasa/perbankan tersebut dapat dikenai sankis, dari sanksi administrasi sampai pada sanksi pencabutan izin usaha. ${ }^{66}$

Fakta yang tak dapat dibantah dari ketentuan Kerahasiaan Bank ini, peralihannya lebih didominasi dari arahan opini nasabah. Perkembangannya diakui sebagai hak asasi manusia. Sejak awal bank sudah meletakkan eksistensi peraturannya tergantung mutlak kepada kepercayaan dari para nasabahnya yang mempercayakan dana dan jasa-jasa lain melalui bank. ${ }^{67}$

Sebagaimana diketahui, di Indonesia proses perubahan ketentuan Kerahasiaan Bank pada Pasal 37 Undang-Undang No. 14 Tahun 1967 dan Pasal 40 Undang-Undang No. 7 Tahun 1992, semuanya dipengaruhi oleh pandangan

\footnotetext{
${ }^{66}$ Marnia Rani, “Perlindungan Otoritas Jasa Keuangan Terhadap Kerahasiaan Dan Keamanan Data Pribadi Nasabah Bank" 2, no. 1 (2014): 14.

${ }^{67}$ Gazali dan Usman, Hukum Perbankan, 487.
} 
Kerahasiaan Bank Kontra..

masyarakat yang tidak puas atas rumusan terkait ruang lingkup Kerahasiaan Bank yang ada dalam pasal tersebut. ${ }^{68}$

Terlihat bahwa nasabah simpanan atau investor lebih dominan pengaruhnya, ketimbang

nasabah peminjam dan pengguna jasa lainnya. Sebenarnya bank bisa saja kukuh dengan ketentuan awal Kerahasiaan Bank, melakukan proses politik dan mempengaruhi pembuat peraturan untuk tidak mempersempit ruang lingkup Kerahasiaan Bank. Logikanya bahwa semakin peraturan Kerahasiaan Bank menjadi ketat dan sama sekali tidak bisa ditembus, maka semakin pula banyak nasabah keseluruhan yang tertarik menggunakan jasanya, tentu tanpa memilah nasabah nakal atau nasabah patuh hukum. Tetapi sekali lagi, nasabah penyimpan mendominasi peralihan ketentuan ini, selanjutnya bank pun mengamini.

Dalam kajian alternatif pandangan Politik Hukum Ekonomi, fenomena peralihan Kerahasiaan Bank lebih memperlihatkan alternatif pertama yaitu proteksi. Terbukti dari tujuan pemberlakuan hukum yang banyak mengarah pada perlindungan terhadap nasabah. Sanksi-sanksi bagi pihak bank serta pihak afiliasi menjadi pelengkap ketegasan muatan proteksi dalam Politik Hukum dari Kerahasiaan Bank.

b. Akses Informasi Perpajakan

Dalam penelilitan yang dilakukan peneliti sebelumnya, berkaitan dengan ketentuan Akses Informasi Perpajakan, diketemukan bahwa lahirnya PERPU NO.1 TAHUN 2017 (PERPU No. 1 Tahun 2017) yang kemudian disahkan menjadi UU NO. 9 TAHUN 2019 (UU No. 9 Tahun 2017) dipengaruhi oleh arah politik pemerintah yang sedang meningkatkan penerimaan kas negara dan pertumbuhan ekonomi. ${ }^{69}$

Upaya serius Indonesia dalam mendukung arah politik tersebut terlihat sejak pemerintah menerbitkan aturan Tax Amnesty, lalu memberanikan diri untuk ikut dalam perjanjian internasional AEOI, meski sempat dilabeli sebagai negara yang "Patuh Sebagian" (Partly-Compliant), hal ini tidak lain karena kewenangan Akses

\footnotetext{
${ }^{68}$ Gazali dan Usman, 496-501.

${ }^{69}$ Faizin, “The Sharia Law Politics Law in Indonesia Year 2008-2017," 388.
} 
Informasi Perpajakan tersandung oleh ketentuan Kerahasiaan Bank. ${ }^{70}$ Di sisi lain, Kerahasian Bank dinilai oleh sebagian besar negara di dunia sebagai ketentuan yang memberi karpet merah kepada praktik pencucian uang. ${ }^{71}$

Pola Politik Hukum Akses Informasi Perpajakan merupakan politik vertikal yaitu murni dari dorongan pemerintah sebagai konsekuensi dari perjanjian internasional AEOI. Tidak ada dorongan dari masyarakat, dan tidak ada pula permulaan narasi yang terbangun di lingkaran legistatif. ${ }^{72}$ Ketentuan ini lebih dominan sebagai aturan lanjutan dari perjanjian Internasional yang diturunkan ke ranah domestik.

Jika ditarik dalam kajian alternatif pandangan Politik Hukum Ekonomi nampak bahwa tidak ada muatan kontrak politik di dalamnya, sehingga dapat diartikan sebagai ketentuan yang masih bermuatan proteksi terhadap negara. Manfaat serta tujuan Akses Informasi Perpajakan mendorong Indonesia kepada agenda yang menuju pada stabilitas ekonomi dan keamanan negara.

\section{Kebermaksudan (Maqashid) : Pola Penyelesaian Pertentangan}

Tak dapat disangkal bahwa perluasan dimensi analisis terhadap suatu masalah telah memberikan pemahaman yang lebih bijak ketimbang proses dengan hanya mengandalkan pandangan monodimensi, sudut pandang yang hanya menimbang satu sisi seringnya salah-benar dalam penghakiman. Terasajuga dalam kajian Maqashid Syari'ah Multidimensi ini. Pertentangan antara ketentuan Kerahasiaan Bank dan Akses Informasi Perpajakan tidak serta-merta mengharuskan salah satunya dihapuskan atau disalahkan, tetapi harus dikonsiliasi kepada satu pola yang memberi peluang untuk dapat bersinergi. Peneliti telah menilai ada dua pola yang memungkinkan untuk menjadi penyelesaian.

\section{a. Kebermaksudan Prioritas}

Pemahaman maksud dari objek penelitian menghantarkan peneliti pada pemahaman filosofis terkait ketentuan. Kerahasiaan Bank mengandung maksud perlindungan nasabah (hifzul $m \bar{a} l$ ), di lain sisi Akses Informasi Perpajakan mengandung maksud pembangunan negara (ulil amri). Dua maksud dari objek

\footnotetext{
${ }^{70}$ Faizin, 389.

${ }^{71}$ Balakina dan Masciandaro, Banking Secrecy And Global Finance, 7.

${ }^{72}$ Faizin, "The Sharia Law Politics Law in Indonesia Year 2008-2017," 390.
} 
penelitian bisa berjalan beriringan tanpa harus menghapuskan yang lain, sebab secara fungsi keduanya memiliki perjuangan yang sama baiknya.

Upaya yang bisa dilakukan demi keberjalanan dua maksud tersebut yaitu pola penyelesaian dengan menimbang maksud yang harus diprioritaskan terlebih dahulu, pola ini disebut oleh peneliti sebagai pola Kebermaksudan Prioritas. Timbangan prioritas dapat menggunakan aspek darurat dalam kebutuhan publik. Analoginya, jika salah satu maksud kedudukannya lebih dominan sebagai kebutuhan publik yang mendesak, maka maksud tersebut harus didahulukan dari maksud yang lain, tetapi tanpa menghapuskan seutuhnya atau menafikan maksud yang lain.

Dalam objek penelitian, kebutuhan mendesak lebih dominan kepada pembangunan negara. Mengingat kondisi ekonomi Indonesia yang sedang membutuhkan unsur dukungan dalam pertumbuhannya, secara singkatnya pemerintah sedang memacu pemasukan kas negara melalui perpajakan. Prioritas kepada ketentuan Akses Informasi Perpajakan menjadi logis untuk didukung, tetapi tanpa harus menghapuskan secara utuh ketentuan Kerahasiaan Bank. Kandungan maksud Kerahasiaan Bank berupa perlindungan nasabah harus tetap dijaga, meski terdapat perubahan mekanisme terkait ketentuannya.

Gambar 1

Pertentangan Hukum Dan Dampaknya

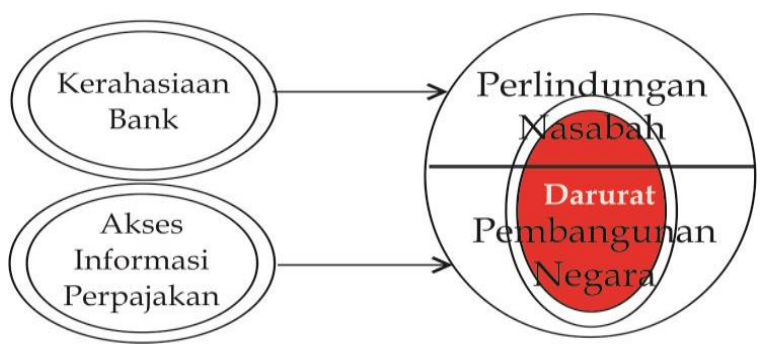

\section{b. Kebermaksudan Proteksi}

Analisis multidimensi dari objek penelitian juga menghasilkan bahwa sebenarnya kedua maksud antara perlindungan nasabah dan pembangunan negara dapat bertemu dalam satu nilai. Pertemuan nilai ini oleh peneliti disebut sebagai Kebermaksudan Proteksi. Setelah melewati langkah analisis dan pendalam yang secara seksama dalam pandangan multidimensi, Kebermaksudan Proteksi yang diketemukan yaitu berupa Kesehatan Nasabah. 
Dalam konteks penelitian, Kesehatan Nasabah yaitu kondisi nasabah yang terlindungi secara hukum haknya (perlindungan nasabah) dan patuh secara hukum dalam menjalankan kewajibannya (pembangunan negara). Dengan kalimat lain, Kesehatan Nasabah diartikan sebagai nilai yang dapat mempertemukan dua maksud proteksi dari Kerahasiaan Bank dan Akses Informasi Perpajakan.

Dengan menawarkan Kesehatan Nasabah sebagai prinsip baru di Perbankan ke depan, akan mengurangi stigma bahwa keberadaan Akses Informasi Perpajakan yang diprakarsai oleh pemerintah memiliki dampak penghapusan terhadap Kerahasiaan Bank secara membabi buta. Dalam kondisi ini lah, pola Kebermaksudan Proteksi berbentuk Kesehatan Nasabah memiliki fungsi sebagai pola penyelesaian dari pertentangan objek penelitian, serta konsiliasi dari kedua maksud ketentuan.

Secara praktiknya, jika ketentuan yang dirancang dalam industri Perbankan kedepan berlandaskan pada prinsip Kesehatan Nasabah, maka akan memungkinkan dapat melahirkan ketentuan yang mengakomodir perlindungan nasabah (maksud dari Kerahasiaan Bank) sekaligus pembangunan negara (maksud dari Akses Informasi Perpajakan). Sehingga, eksistensi Kerahasiaan Bank masih berkontribusi dalam menyakinkan kepercayaan nasabah, sementara hukum akan susah dianulir oleh pihak tak patuh hukum dengan keberadaan Akses Informasi Perpajakan. Pada akhirnya, kedua maksud luhur tersebut dapat berjalan beriringan dalam membangun industri Perbankan.

\section{Gambar 2}

Prinsip baru dalam menghadapi pertentangan hukum

\section{Kesimpulan}

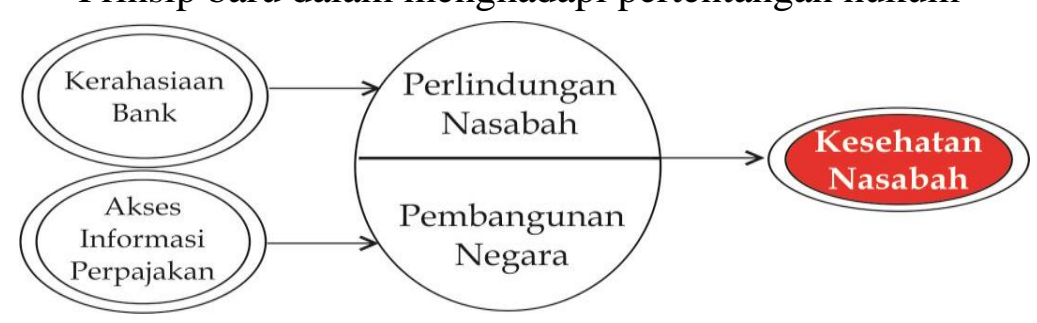

Berdasarkan pemetaan dan analisa yang telah diuraikan di pembahasan, maka dapat disimpulkan bahwa dalam pembahasan tentang Pertentangan Kerahasiaan Bank Dan Akses Informasi Perpajakan ini, dalam perspektif kajian yuridis UU NO. 9 TAHUN 2019 tidak melampaui asas yuridis, dan pembatalan ketentuan Kerahasiaan Bank dalam bidang perpajakan adalah tawaran yang paling memungkinkan, meskipun 
Kerahasiaan Bank Kontra..

secara filosofis Kajian yuridis terjebak dalam pandangan monodimensi dan cenderung memiliki kesamaan dengan metode klasik yaitu nasakh/penghapusan. Adapun dalam perspektif kajian Maqashid Syari'ah Multidimensi, pertentangan sebuah ketentuan hukum bisa dengan menggunakan pertimbangan yang hanya satu sudut pandang saja, melainkan bisa juga menggunakan sudut pandang maksud dari ketentuan. Sehingga dengan kajian maqashid syari'ah multidimensi ini, terdapat dua tawaran pola penyelesaian pertentangan, Maksud/tujuan Prioritas dengan menimbang kondisi darurat, selanjutnya Maksud/tujuan Proteksi yang menggabungkan maksud Kerahasiaan Bank (perlindungan nasabah), dan Akses Informasi Perpajakan (pembangunan negara) menjadi sebuah prinsip baru, yaitu Prinsip Kesehatan Nasabah.

\section{Daftar Pustaka}

Ahmad Erani Yustika. Ekonomi Politik. Yogyakarta: Pustaka Pelajar, 2011.

Al-Sheikh, Abdullah bin Muhammad bin Abdurahman bin Ishaq. Tafsir Ibnu Katsir. Vol. II. Bogor: Pustaka Imam Syafii, 2000.

Arfan, Abbas. "Maqasid Al-Syariah Sebagai Sumber Hukum Islam, Analisis Terhadap Pemikiran Jasser Auda." Al-Manahij 07, no. 01 (Juli 2013).

Asshiddiqie, Jimly, dan M. Ali Safa'at. Teori Hans Kelsen Tentang Hukum. Jakarta: Konpress, 2014.

Auda, Jasser. Al-Maqashid Untuk Pemula. Diterjemahkan oleh Ali Abdelmon`im. Yogyakarta: SUKA Press, 2013.

- - - Membumikan Hukum Islam Melalui Maqashid Syariah. Diterjemahkan oleh Rosidin dan 'Ali 'Abd el-Mun'im. Bandung: Mizan, 2015.

Badruzaman, Abad. "Dari 'Illah Ke Maqasid: Formula Dinamisasi Hukum Islam Di Era Kekinian Melalui Pengembangan Konsep Maqasid." Ijtihad 14, no. 01 (Juni 2014).

Balakina, Olga, dan Donato Masciandaro. Banking Secrecy And Global Finance. New York: Palgrave Macmillan, 2015.

Chaikin, David. "Policy And Fiscal Effects Of Swiss Bank Secrecy." REVENUE LAW JOURNAL 15, no. 01 (Januari 2005). 
Faizin, Mu'adil. “Analisis Maqāșid Asy-Syarī’ah Terhadap Prinsip Kerahasiaan Bank Dan Akses Informasi Perpajakan." Masters, UIN SUNAN KALIJAGA YOGYAKARTA, 2018.

Faizin, Mu'adil. "Hak Asasi Manusia Dalam Pemikiran Yusuf Qaradhawi." Al-Mazahib 5, no. 1 (1 Juni 2017).

Faizin, Mu'adil. "The Sharia Law Politics Law in Indonesia Year 2008-2017." Adzkiya: Jurnal Hukum dan Ekonomi Syariah 5, no. 2 (1 September 2017).

Gazali, Djoni S., dan Rachmadi Usman. Hukum Perbankan. Jakarta: Sinar Grafika, 2012.

G.P, M.Arskal Salim. Etika Intervensi Negara Perspektif Etika Politik Ibnu Taimiyah. Jakarta: Logos, 1998.

Hakim, Muhammad Lutfi. "Pergeseran Paradigma Maqasid Al-Syari'ah: Dari Klasik Sampai Kontemporer." Al-Manahij 10, no. 01 (Juni 2016).

Hasan, Mufti. "Mekanisme Penyelesaian Ayat Kontradiktif Berbasis Maqasid AlShariah: Studi Terhadap Ayat Perkawinan Beda Agama." THEOLOGIA 28, no. 01 (Juni 2017).

Idris, Miftah. "Kerahasiaan Bank Suatu Tinjauan Dalam Aturan Hukum Perbankan Syariah Di Indoesia." Al-Amwal : Journal of Islamic Economic Law 1, no. 1 (20 Mei 2019).

Jundiani. Pengaturan Hukum Perbankan Syariah Di Indonesia. Malang: UIN Malang Press, 2009.

Kasmir. Dasar-Dasar Perbankan. Jakarta: Raja Grafindo, 2012.

Khariri. "Penalaran Hukum Islam (Upaya Mensinergikan Metode al-Tsawabit dan alMutaghayyirat)." Al-Manahij 10, no. 01 (Juni 2016).

Knobel, Andres, dan Markus Meinzer. "The End Of Bank Secrecy? Bridging The GapTo Effective Automatic Information Exchange." Tax Justice Network, 10 November 2014.

Mahfud MD", Moh. Membangun Politik Hukum, Menegakkan Konstitusi. Jakarta: Rajawali Pers, 2010.

Maulidi. "Metodologi ljtihad Fikih Kontemporer (Telaah Atas Pemikiran Yusuf AlQaradawi)." Al-Manahij 8, no. 01 (Januari 2014).

Maulidi, Maulidi. "Paradigma Progresif dan Maqashid Syariah: Manhaj Baru Menemukan Hukum Responsif." Asy-Syir'ah Jurnal Ilmu Syari'ah dan Hukum 49, no. 2 (2015). 
Kerahasiaan Bank Kontra..

Muttaqin, Muhammad Ngizzul, dan Iffatin Nur. "Menelusuri Jejak Maqashid Syari'ah Dalam Istinbath Hukum Imam Hambali." AHKAM 07, no. 01 (Juli 2019).

PERPU No. 1 Tahun 2017 Tentang Akses Informasi Keuangan Untuk Kepentingan Perpajakan, (2017).

Rani, Marnia. "Perlindungan Otoritas Jasa Keuangan Terhadap Kerahasiaan Dan Keamanan Data Pribadi Nasabah Bank." SELAT 2, no. 1 (Oktober 2014).

- - . "Perlindungan Otoritas Jasa Keuangan Terhadap Kerahasiaan Dan Keamanan Data Pribadi Nasabah Bank" 2, no. 1 (2014).

Safriadi, Safriadi. “Kontribusi Ibn 'Āsyūr Dalam Kajian Maqāsid Al-Syarīah.” Jurnal IImiah Islam Futura 15, no. 2 (1 Februari 2016).

Samsul Anwar. "Teori Pertingkatan Norma Dalam Ushul Fikih." Asy-Syir'ah 50, no. 01 (Juni 2016).

Samuddin, Rapung. Fiqih Demokrasi. Jakarta: GOZIAN Press, 2013.

Surono, Agus. Fiksi Hukum Dalam Pembuatan Peraturan Perundang-Undangan. Jakarta: UAI, 2013.

Sutendi, Adrian. Hukum Pajak. Jakarta: Sinar Grafika, 2011.

Syarifuddin, Amir. Ushul Figh Jilid 2. Revisi. Jakarta: Kencana, 2014.

Taimiyah, Ibn. Siyasah Syar'iyah. Diterjemahkan oleh Rofi' Munawar. Surabaya: Risalah Gusti, 2005.

UU No. 21 Tahun 2008 tentang Perbankan Syariah (2008).

UU No. 9 Tahun 2017 Tentang Penetapan PERPU No. 1 Menjadi Undang-Undang (2017).

UU No. 28 Tahun 2007 Tentang Perubahan Ketiga Atas UU No. 6 Tahun 1983 Tentang Ketentuan Umum Dan Tata Cara Perpajakan (2007).

Wahyudi, Yudian. Hukum Islam Antara Filasafat Dan Politik. Yogyakarta: Pesantren Nawasea Press, 2015.

Yaqin, Ainol. "Revitalisasi Maqashid Al-Syari'ah dalam Istinbath Hukum Islam: Kajian atas Pemikiran Muhammad Al-Thahir Ibnu 'Asyur." Asy-Syir'ah Jurnal Ilmu Syari'ah dan Hukum 50, no. 2 (2016). 